\title{
Glioblastomas: are individual therapies required for individual tumors?
}

\author{
Carl Friedrich Classen \\ Correspondence: carl-friedrich.classen@med.uni-rostock.de \\ Pediatric Oncology, University Children's Hospital, Rostock, Germany.
}

\begin{abstract}
In contrast to most other malignant diseases, especially in children, up to now glioblastoma multiforma is a lethal diagnosis for most patients. Operation and radiotherapy are very effective to reduce the tumor burden, however, a strong adjuvant treatment is lacking. Due to rapid infiltrative growth, relapse is common, which can then no more be controlled in most of the cases. Many data are available on the cellular signaling and regulation networks in glioblastomas, particularly in the different growth factor receptor dependent pathways upregulated in these tumors. Numerous substances acting in a molecular way to inhibit these are at hand, but still, although these compounds showed some activity in individual patients, larger studies aiming at an improvement of the cure rate were generally disappointing. One reason for this might be the heterogeneity of tumors. Novel methods of molecular analysis showed that they are extremely heterogeneous - regarding genetic, epigenetic or signaling regulation, receptor expression, or interaction with stroma, vasculature, or the immune system. Another striking fact is that in glioblastomas of children and adolescents, completely different patterns of molecular setup are found compared to those in adults. Thus, probably a different therapeutical approach would be required for each tumor, using an individually selected panel of treatment modalities. For such an approach, besides many laboratory hurdles, also the concept of evidence based medicine has to be developed further to handle individualized medicine.
\end{abstract}

Keywords: Glioblastoma, individualized therapy, signaling, molecular signature, brain tumor

\section{Introduction}

\section{Glioblastoma: a scourge to mankind}

Glioblastoma multiforme (GBM) accounts for up to $60 \%$ of all malignant primary brain tumours in adults $[1,2,3]$ with 2-3 cases per 100,000 inhabitants per year in Europe or North America, while in children it accounts for only about $5 \%$ of the brain tumors, with an incidence even below 0.1 per 100,000 inhabitants [4,5].

Therapy first relies on neurosurgery and irradiation which both are effective, however, may rarely lead to cure. Until the work of Stupp et al., [2,6] from 2005 it had not even been generally accepted that in adults systemic therapy is of any benefit at all. By Stupp and coworkers, it was shown in a randomized study that treatment with oral Temozolomide, a cytostatic drug, acting as an alkylating agent, leads to a limited, yet significant prolongation of survival with acceptable toxicity. Previously, for example a large clinical study examining combined Procarbacin, CCNU (Lomustin) and Vincristin (PCV), had reported a very modest gain of survival with radiotherapy plus PCV versus 13 months with radiotherapy alone; however, the toxicity connected with such a therapy approach led to a significant debate regarding the actual benefit for the patient $[1,3,7,8]$. In children, systemic approaches have already been standard in therapy back from the nineties, however, here, the cure rate was also dismal - although in general, it is slightly better than in adults [9].

Many new concepts have been developed after the work of Stupp et al., and an enormous lot of different systemic therapy approaches have been developed in the last years - besides cytostatic chemotherapy, multiple agents with molecular targets, agents inducing differentiation or cell cycle arrest, anti-angiogenetic approaches, or immunotherapy, nanoparticles, oncolytic viruses, and others $[\mathbf{1}, \mathbf{7}, \mathbf{8}]$. But, there still is a large gap between optimistic concepts and final results: in each of these therapies, clinical studies, although initiated with much enthusiasm, ended up with disappointing results - none of the new targeted substances, for example, could, as monotherapy, improve significantly the prognosis of glioblastomas in a larger number of patients. And more than five years after the Stupp paper, there still is no therapeutical concept representing a reliable additional benefit for this group of patients.

This fact of course leads to several further questions. First, it has to be asked whether a greater number of substances should be used at once, if acceptable from the point of risks and toxicities due to combination or interaction of the substances. And second, whether the substances used should be selected in a more individual way, based, for example, on the molecular profile of the patient's tumor.

As an example, O6-methylguanine-DNA-methyltransferase (MGMT) gene methylation has already reached significance for clinical practice, as described below. Knowing that this molecular pattern leads to much higher

() 2013 Carl Friedrich Classen licensee Herbert Publications Ltd. This is an Open Access article distributed under the terms of Creative Commons Attribution License (http://creativecommons.org/licenses/by/3.0). This permits unrestricted use, distribution, and reproduction in any medium, provided the original work is properly cited. 
sensitivity towards Temozolomide, patients may thus be selected to be treated in a more specific way, improving results $[7,10]$.

Besides, a lot of difficulties are related to the definitions of response, remission or relapse. On the one hand, the existing imaging methods have some limitations in defining the lesions exactly, which, in glioblastoma, usually are composed of areas of the tumor itself, edema, necrosis, infiltrated normal tissue, reactive hyperemia etc. [11-15]. On the other hand, all what is particularly important for a patient in a most likely palliative situation besides survival, i.e., mental condition, brain function, and quality of life, is difficult to assess and compare exactly $[5,15]$.

Keeping the patients' general situation in consideration we also have to ask whether, on the one side, toxicity, even severe one, may still be accepted due to the fact that it is the patient's only chance anyway, or whether, basically for the same reason, since it is probably going to be a palliative situation for most patients, any therapy should be focused on quality of life rather than on oncological responses that might just mean suffering for a person who still has only a very limited life expectancy [9].

All these aspects clearly point in favor of a more individualized approach in future glioblastoma therapy. However, as long as medicine in general - including establishment of therapy standards and approval of drugs for medical use - is done on the basis of statistical evidence, sufficient patient numbers will have to be treated using equal schedules, which, at best, should also include only a limited number of substances given together to enable the establishment of clear dose-effect relationships.

To solve this problem, probably a completely new approach both in the clinical, but also the in vitro research will be required.

\section{Genetics}

An enormous lot of genetic alterations in glioblastomas has been described. However, most of these are not strictly associated with a particular clinical phenotype [16]. And in pediatric glioblastoma, the distribution of clinical and genetic factors again is different $[4,9]$.

Traditionally, glioblastomas are separated into the two subgroups, primary and secondary tumors $[7,16]$. The secondary glioblastomas, accounting for about 5 per cent of the adult tumors, develop stepwise from benign brain tumors, particularly diffuse astrocytomas or oligodendrogliomas [16]. In the benign lesions and subsequently in glioblastomas of the secondary type, mutations of the isocitrate dehydrogenase 1 (IDH-1) gene are a common, however not general finding [16]. IDH-1 preferentially catalyzes the nicotinamide dinucleotide phosphate-dependent reduction of alpha-ketoglutarate to hydroxyglutarate, resulting in accumulation of the latter $[7,16]$. As a result of the mutations, changes in the expression of numerous other genes related to intracellular
Table 1. Markers for discrimination of glioblastomas and for individualized therapy approaches $[7,8,16]$.

\begin{tabular}{c}
\hline gene mutations / deletions \\
\hline IDH-1 \\
PTEN \\
PI3K \\
p53 \\
EGFR \\
NF1 \\
CDKN2A \\
RAS \\
\hline gene amplifications \\
EGFR \\
PDGFRA \\
AKT \\
MET \\
epigenetic status \\
MGMT methylation \\
Histone deacetylation \\
pathway activation status \\
RAS/RAF kinases \\
AKT-mTor pathway \\
vascular endothelial growth factor receptor (VEGFR) \\
\hline target expression (on tumor cells, stroma, or vasculature) \\
Integrins \\
EGFR \\
PDGFRA \\
VEGF
\end{tabular}

metabolism and even to epigenetic control are seen $[7,16]$. Since IDH-1 mutations are related to a better prognosis and might help to differentiate between primary and secondary glioblastoma, they have a valuable diagnostic potential, however, therapeutic approaches using the IDH-1 pathway are not described $[4,7,16]$.

In primary tumors, manifesting themselves as highgrade tumors from the beginning, phosphatase and tensin homologue (PTEN) mutations are a common, however, not general finding $[8,16]$.

These genetic differentiations, however, are by far not the only one observed in glioblastomas. Particularly common genetic factors in high grade gliomas include classical oncogenetic alterations like mutations in p53 or PTEN $[7,8,16]$, which are very frequent in glioblastomas, while microsatellite instability is only observed in a small subgroup [16]. Loss of heterozygosity in numerous chromosomes may also lead to functional alterations of tumor suppressor genes [16].

None of these mechanisms, however, do currently imply a mechanism that could be used for a therapeutical approach; at best, they may to some degree be used as prognostic markers [16].

An overview of genetic and metabolic alterations observed in glioblastomas is given in (Table 1).

\section{Growth factors and their receptors}

In some contrast to the characterization of primary and secondary tumors, four distinct molecular subclasses were defined based on the Cancer Genome Atlas (TCGA), corresponding to stages in neurogenesis, i.e., the proneural, neural, classic, and mesenchymal subtypes $[16,18]$. Besides 
the classical oncogenes, alterations of different growth factor receptors, are of relevance for this discrimination. So-called proneural glioblastomas have IDH-1 mutations and p53 and platelet derived growth factor receptor alpha (PDGFRA) alterations, and they correlate with a better prognosis and younger age. Classic glioblastomas show high-level amplification of epidermal growth factor receptor (EGFR), monosomy of chromosome 10, and deletion of cyclin dependent kinase 2A (CDKN2A). Neural glioblastomas are characterized by expression of neuron markers, and resemble most a normally differentiated brain tissue. Mesenchymal glioblastomas show deletions or mutations of the neurofibromatosis type 1 gene (NF1) and expression of chitinase 3-like 1 gene (YKL-40/CHI3L1) and hepatocyte growth factor receptor (MET) alterations $[16,18]$.

These growth factor receptors, acting as tyrosine kinases, transmit their signal into a complex intracellular network involving mainly two pathways, i.e., the rat sarcoma kinase/ rat fibrosarcoma kinase (RAS/RAF kinases) and the protein kinase B-mamalian target of rapamycin (AKT-mTor) pathway. Thus they dictate the behaviour of the cells - including processes of differentiation, cell cycle progress, proliferation, migration, or apoptosis $[8,16,19]$. Therefore, the relevance of growth factor receptor alterations in glioblastomas is evident. The receptor most involved in such oncogenic alterations certainly is the epidermal growth factor receptor $[16,20-23]$.

First, there are cases showing an amplification of the epidermal growth factor receptor (EGFR) gene - which is typically seen in primary glioblastomas. This may be caused by a focal amplification of EGFR or an amplification of the complete chromosome 7, containing EGFR, and other genes. Further, EGFR amplification may appear as double minutes (small fragments of extrachromosomal DNA), and extra copies of EGFR have also been described inserted into different loci on chromosome 7 [16]. Second, mutations in the EGFR gene may result in a constitutively overactivated receptor pathway, which is classically seen in form of the epidermal growth factor receptor variant III (EGFRvIII), caused by a deletion in the extracellular part of the receptor [16]. EGFR point mutations have been identified as well, and, particularly in children, EGFRvIll deletion mutations exist without activating characteristics [4]. The EGFR signal transduction system is target of numerous types of molecular therapies, both aiming at the receptor - with its extrecellular or intracellular components - or at the intracellular signaling network which, itself is connected with the complex regulation pathways of the PI3K/AKT, PTEN, and RAS/RAF pathways $[4,8,16]$.

Several molecular therapies aiming at the EGFR have been developed in the previous years. First, antibodies acting both by EGFR-blockade or induction of cytotoxicity, like nimotuzumab and cetuximab were developed $[4,16]$. Numerous phase I studies have already shown some therapeutic benefit; the potential of these compounds in single drug application, however, certainly is limited [9].
As inhibitors of the signal transduction from the receptors to intracellular pathways, erlotinib and gefitinib were developed that showed acceptable toxicity in phase I studies, however were did not have a convincing antitumor effect as monotherapy $[4,19,24]$.

Although the EGFR system probably plays the most important role in the regulation of growth and differentiation in glioblastoma, numerous other growth factor receptors are also activated in glioblastomas and thus represent a possible aim for targeted therapies, eg., the platelet derived growth factor receptor (PDGFR) and the vascular endothelial growth factor receptor (VEGFR) which both, particularly the latter, also are of relevance for angiogenesis regulation in glioblastomas. Both antibodies - like bevacizumab - and small molecular inhibitors like imatinib - have thus been applied in experimental glioblastoma therapy $[4,11,12,15,16]$.

Glioblastoma multiforme cells also secrete hepatocyte growth factor/scatter factor (HGF/SF), which binds to its receptor, the MET receptor tyrosine kinase [25]; this appears to be associated to the grade of malignancy. HGF/SF expression is typically associated with invasive behaviour. MET and HGF/SF are expressed in invasive cells from primary human glioblastomas; HGF/SF is a potent chemotactic factor for glioblastoma cell lines. This suggests that MET - HGF/ SF signaling could also represent an autocrine motility loop leading to the invasive and migratory characteristics typical for high grade gliomas. Furthermore, in several cancer models, MET signaling has been described to be a factor rescuing cells from drug-induced apoptosis [19].

As mentioned above, the further intracellular signal transduction pathways of these growth factor receptors share multiple elements. Here, for possible therapeutic interventions, the two central elements are the PI3 kinase AKT and the RAS - ERK systems, particularly in downstream signaling of the EGF-receptor. Although mutations in the RAS genes have rarely been observed in malignant gliomas [16], inactivating mutations and deletions have been identified in their inhibitory tumor suppressor gene NF1 [16]; these are, however, currently not relevant for therapeutic approaches [20]. Mutations in PIK3CA and PIK3R1, coding for different $\mathrm{PI} 3$-kinase catalytic subunits have also been described in glioblastoma, leading to an over-activated phenotype [16]. Thus, both the RAS-ERK and the PI3-kinase AKT systems may appear as possible targets for novel therapies. As a RAS-RAF inhibitor, Sorafenib $[\mathbf{9}, 20]$ has been used in some minor clinical studies that were, unfortunately, not really encouraging [20]. Multiple agents have been established for the pharmaceutical inhibition of the PI3-kinase - protein kinase C - AKT system, both direct inhibitors like BEZ235 and XL765 [20], Enzastaurin [7,21] and numerous inhibitors of mTor (mammalian target of Rapamycin), the most important downstream target of AKT - like sirolimus, temsirolimus, everolimus, and deforolimus [20,21].

An overview of intracellular pathways relevant in gliob- 


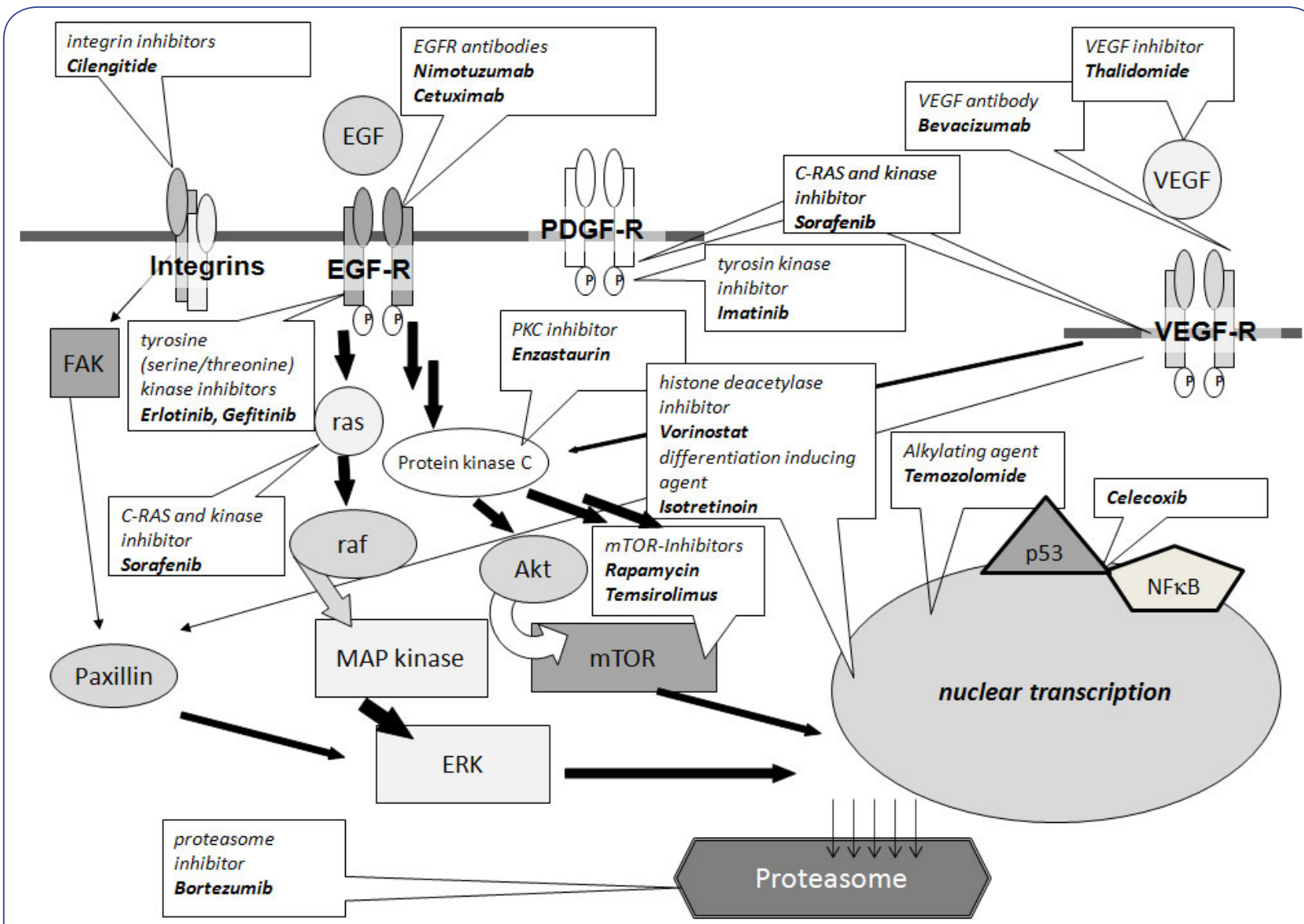

Figure 1. Metabolic pathways and molecular inhibitors in glioblastomas $[\mathbf{7 , 8 , 1 6}$.

lastomas, with different molecular inhibitors, is given in (Figure 1 and Table 2).

\section{Epigenetics}

Besides genetic factors, epigenetic programing of the cells, particularly gene methylation and histone deacetylation, are of importance for the malignant behaviour of glioblastoma cells $[1,7,8,16,20]$.

For many years it has been described that tumors in which the promoter of the gene encoding the enzyme O6-methylguanine-DNA methyltransferase (MGMT) is methylated are much better protected against the effects of the cytostatic agent Temozolomide (TMZ) $[7,8]$. While numerous cytostatic drugs, for example Nitroso-Urea, Vincristin, Procarbacine, have been applied in glioblastoma over decades in adults, and even more in children [4], TMZ was actually the first one in which a therapeutic benefit was actually shown in a randomized study [6]. While it is certainly still open whether other cytostatics might in future turn out to be helpful in particular subgroups of glioblastoma, the focus of research shifted from cytostatic to molecular therapies; both due to lower toxicity and the hope, at least, to discover better efficacy.

TMZ is a methylating agent that can be applied orally with a profile of side effects that may be handled easier than in most other cytostatic drugs. Due to this fact, it was first primarily used as palliative treatment. MGMT is a DNA repair protein removing alkyl groups from DNA that thus confers resistance to alkylating agent chemotherapy $[1,10]$. Its relevance has been particularly shown for glioblastomas treated with TMZ - in which the MGMT promoter methylated tumors showed a significantly better response to therapy. This finding may lead to different consequences. One may be to exclude patients of the methylated type from any TMZ treatment. Since TMZ efficacy is reduced, but not to zero in these patients, this may perhaps help to improve study data, however, does not mean any help for the patients. Or one might try find methods in order to block MGMT promoter demethylation. This may either be achieved by a novel, that is metronomic application mode of temozolomide administration leading to depletion of intratumoural MGMT as suggested in previous trials and investigations [26-28] - or, finally, there might a search for agents inhibiting MGMT demethylation leakage of calcium from into the cytosol [29].

In any case, the MGMT methylation status apparently is a classical example for a situation in which the efficacy of a drug depends on particular properties of the individual 
Carl Friedrich Classen Journal of Cancer Therapeutics \& Research 2013,

http://www.hoajonline.com/journals/pdf/2049-7962-2-17.pdf

doi: $10.7243 / 2049-7962-2-17$

Table 2. Drugs used in the treatment or being investigated for the treatment of glioblastoma.

\begin{tabular}{|c|c|c|c|}
\hline drug & mechanism & side effects (in short) & $\begin{array}{l}\text { literature } \\
\text { (example) }\end{array}$ \\
\hline Temozolomide & $\begin{array}{l}\text { cytostatic (alkylating } \\
\text { agent) }\end{array}$ & myeolsuppression & $4,6,7,24$ \\
\hline Nimotuzumab & EGFR antibody & allergic reactions & 4,15 \\
\hline Cetuximab & EGFR antibody & allergic reactions & 4,15 \\
\hline Enzastaurin & PKC beta inhibitor & $\begin{array}{l}\text { lymphopenia, } \\
\text { thrombopenia }\end{array}$ & 20 \\
\hline Imatinib & $\begin{array}{l}\text { tyrosine kinase } \\
\text { inhibitor }\end{array}$ & $\begin{array}{l}\text { myelosuppression } \\
\text { inhibiting c-kit, PDGFR, } \\
\text { BCR-ABL }\end{array}$ & $12,15,16$ \\
\hline Sorafenib & $\begin{array}{l}\text { tyrosine (and serine/ } \\
\text { threonine) kinase } \\
\text { inhibitor }\end{array}$ & $\begin{array}{l}\text { diarrhea, skin reactions, } \\
\text { leukopenia inhibiting } \\
\text { VEGFR, PDGFR, and } \\
\text { C-RAF }\end{array}$ & 9,20 \\
\hline Erlotinib & $\begin{array}{l}\text { tyrosine kinase } \\
\text { inhibitor inhibiting } \\
\text { EGFR }\end{array}$ & diarrhea, skin reactions & 19,24 \\
\hline Gefitinib & $\begin{array}{l}\text { tyrosine kinase } \\
\text { inhibitor inhibiting } \\
\text { EGFR }\end{array}$ & diarrhea, skin reactions & 19,24 \\
\hline Rapamycin & mTOR-Inhibitor & $\begin{array}{l}\text { hypertension, skin } \\
\text { reactions }\end{array}$ & 19 \\
\hline Temsirolimus & mTOR-Inhibitor & $\begin{array}{l}\text { thrombocytopenia, } \\
\text { hyperlipidaemia, } \\
\text { asthenia }\end{array}$ & $19,19 a$ \\
\hline Vorinostat & $\begin{array}{l}\text { histone deacetylase } \\
\text { inhibitor fatigue, } \\
\text { diarrhea }\end{array}$ & - & $4,23,28,29$ \\
\hline Isotretinoin & $\begin{array}{l}\text { differentiation } \\
\text { inducing agent }\end{array}$ & $\begin{array}{l}\text { hypertriglyceridemia, } \\
\text { pancreatitis }\end{array}$ & 30,31 \\
\hline Cilengitide & integrin inhibitor & $\begin{array}{l}\text { thrombopenia, flue-like } \\
\text { sympt. }\end{array}$ & 16,41 \\
\hline Bevacizumab & VEGF antibody & bleeding & $10,11,12$ \\
\hline Celecoxib & COX-2-inhibitor & $\begin{array}{l}\text { bleeding, anemia, } \\
\text { thrombosis }\end{array}$ & $32,33,34,35$ \\
\hline Bortezomib & Proteasome inhibitor & $\begin{array}{l}\text { myelosuppression, } \\
\text { fatigue }\end{array}$ & 29 \\
\hline
\end{tabular}

tumor, leading to a requirement for a tumor-dependent therapy stratification $[\mathbf{1 , 7}]$.

Histone deacetylation is another mechanism of epigenetic regulation - which is particularly relevant for the cellular functions of differentiation or proliferation. By inhibition of histone deacetylation, numerous genes that were previously silenced, become activated which may induce a differentiation response. Since in most cases, differentiation leads to an arrest of proliferation and since induction of differentiation has become a mode of therapy in several other malignant diseases - like acute promyelocytic leukemia or neuroblastoma - it was a very interesting observation that the antiepileptic drug Valproic acid, which was given to some glioblastoma patients, does also have an anti-tumor effect [4]. Valproate, acting as a histone deacetylase inhibitor, apparently has an impact on maintanance of stemness, and resistance to DNA damage [7]; it thereby has the potential to sensitize cells to other chemotherapeutic agents [4,30]. Thus, other histone deacetylase inhibitors with less toxicity, such as Vorinostat (suberoylanilide hydroxamic acid, SAHA) are also now

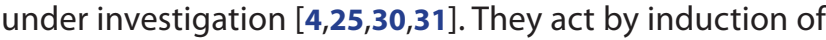
oxidative stress, upregulation of death receptors, cell cycle checkpoint disruption, and upregulation of proapoptotic proteins [30]. Isotretinoin has also been show to induce a differentiation effect in glioblastoma cells and was applied in phase I studies [32,33]. It is still open whether the efficacy of these drugs might also depend on particular properties of the given tumors. As single agents, however, none of them has shown convincing effects.

Further approaches to intracellular mechanisms Among the substances acting on the intracellular metabolism, some appear to have several different modes of action at the same time, and the actual relevance of these has not completely been understood. Non-steroidal antiinflammatory drugs for example, particularly Celecoxib, which inactivates cyclooxygenase- 2 catalyzing the rate-liming step of prostaglandin synthesis from arachidonic acid substrate, were demonstrated to have a significant cytotoxic potential against glioblastoma cells [34-37]. Since it also inhibits tumor cell growth by acting on COX independent targets and even in COX-2-negative hemopoietic cells by induction of cell cycle arrest and apoptosis, it appears to act also in a COX-2 independent manner, possibly by interfering with the nuclear factor kappa-B (NFkB) pathway [34]. NFkB has been extensively studied in immune cells, where it regulates normal activation and differentiation; it is typically activated in malignant cells and is preferentially overexpressed in glioblastomas, however not in all [34]. Another possible interaction partner of Celecoxib is p53; since it was shown that Celecoxib induces DNA damage, leading to p53-dependent G1 cell cycle arrest and autophagy [35]. Further, Celecoxib may cause stress of the endoplasmatic reticulum by leakage of calcium into the cytosol [37] or even inhibition of growth factor signaling [36]. In combination with Temozolomide, Celecoxib has shown significant efficacy in some patients; however, since the exact mode of action is unknown, it is still impossible to predict response in individual patients $[32,36]$.

Another apoproach to intracellular metabolism are proteasome inhibitors. In the proteasomes, proteins are inactivated by ubiquitination, inducing their regular degradation and turnover. Proteasome inhibition may thus lead to sort of a self-intoxication of cells, not only by inhibition of normal regulation and turnover processes in the cell, but also by accumulation of abnormal or dysfunctional proteins leading to endoplasmatic reticulum stress and cell death $[20,37]$. Protein turnover is much more rapid in malignant cells, rendering them more sensitive to proteasome inhibition than normal cells. The proteasome inhibitor, Bortezomib, has used for the treatment of multiple myeloma but also numerous other tumors including glioblastoma $[37,38]$. Both as monotherapy and in combination regimens, it has been applied in phase I studies for glioblastoma, with limited success $[31,38,39]$. 


\section{Stem cells and migrating cells}

A common concept still requiring full verification for many types of malignancy is the idea of malignant stem cells. Thus, a minority of undifferentiated cells with high capacity to divide produces the actual mass of tumor cells, while most of these may perhaps in many ways do harm to the host, however, resembling normally differentiated body cells, they will no more divide. There are even hints indicating that tumor stem cells might even retain the capacity to transdifferentiate into vasculature [40]. So, only an attack aiming at the tumor stem cells might have the potential to cure the disease, while destruction of the tumor mass may only lead to a transient effect. If this concept is true, analyses studying sensitivity of tumor cells towards a therapeutic agent using bulk cells may be futile $[1,23,41]$.

The same would be true if the proportion of invasive and migrating cells had a different cellular makeup than the residual ones. Since often the removal of the main tumor is possible, but the patient experiences a relapse from a site behind the resection margin, obviously it is the invasive and migrating cells that should be the main target of therapy since they will finally cause the relapse distant from the original site of the tumor - sometimes even distant to the irradiation margins [25].

In a recent work, however, Friedmann-Marvinski and colleagues showed that the de-differentiated, stem-like phenotype of glioblastoma cells may be induced by transformation not only of neural stem cells but also differentiated astrocytes, or even mature neurons [42]. This would mean that not only stem but also residual tumor bulk cells might induce relapse tumor formation by perpetuating the cycle of continuous cell replication [42].

\section{The tumor and its surrounding}

Only recently it has gained growing attention that tumors, besides having their own molecular and regulatory properties, also depend substantially from interactions with the surrounding tissue. This is composed of vasculature, matrix and stroma cells, and within these, the immune system, which is, of course, regulated by an extremely complex system of interactions [25].

It can be assumed that any tumor that is visible has already a long history of such interactions behind itself, which lead to a longstanding selection and editing process. Both the tumor and the host are shaped by this process, and certainly in the natural history of a tumor, both cannot be separated from each other. Thus, not only treament attempts aiming at the tumor itself but also those acting on the host - like specific or unspecific immunotherapy may be effective. These should be discussed in particular.

\section{Integrins}

Integrins are heterodimeric proteins at the cellular membrane mediating the interaction of cells with the extracellular matrix $[42,43]$. Numerous different types of integrins bind to individual matrix molecules, eg., fibronectin, collagen, laminin, and others [42]. A particular role for integrins has been described in endothelial cells. The avb5 integrin, for example, is an important co-factor for the VEGF-mediated angiogenesis [43]. The avb3 integrin has been found on endothelial cells of small blood vessels in glioblastomas, but not on normal brain vessels [43]. But these molecules are also expressed on the glioblastoma cells themselves. Many intracellular regulation pathways are influenced by their interaction with matrix molecules, particularly, via paxillin, the Erk pathway $[17,42]$. Thus, integrin inhibitors have been shown to induce apoptosis in glioblastoma cells [42]. This may have the features of autophagy [44]. Further, a possible influence on tumor cell migration - an important factor of malignancy in glioblastoma cells - can be assumed. An interesting correlation with the level of expression of integrins was reported by measuring expression of both the avb3 and avb5 integrins in brain tumor specimens at on the growing edge of the tumor [43].

The therapeutic potential of integrin inhibitors - the paradigmatical being Cilengitide, a avß3 and avß5 specific integrin inhibitor - certainly depends on the expression of the corresponding integrins on the target cells $[42,43]$. In numerous studies both in vitro, in animal models, antiglioblastoma efficacy of Cilengitide has been shown; and clinical studies demonstrated feasibility and some clinical response which was, however, not very impressive in a monotherapy approach [43].

\section{Angiogenesis}

It is well known that glioblastomas not only have a very dense and atypical vasculture, they are also characterized by secretion of multiple proangiogenic molecules, particular vascular endothelial growth factor (VEGF). Vascularization appears to be an important process in tumorigenesis, which is deeply connected with tumor growth, and depends both on factors within the tumor, the surrounding normal vasculature, and the stroma [24]. Besides starving tumors of oxygen and growth factors, anti-angiogenetic therapy may also act on the blood-brain barrier $[7,45]$. Thus, such substances have been applied in the treatment of glioblastomas, particularly Bevacizumab, a humanized monoclonal antibody aimed at vascular endothelial growth factor (VEGF), has shown high response rates in recurrent glioblastomas [7]. This prima vista clear effect yet still is a matter of debate [11-15]. While a reduction of contrast enhancement and intensity in glioblastoma have been shown in bevacizumab treatment, it is still open to which extend these changes might be relevant for survival [11].

The same may be true for another antiangiogenetic approach, using Thalidomide, which is one of the most effective anti-angiogenetic drugs, alone or on combination $[45,46]$.

\section{Immune therapy}

Probably as a result of tumor editing, Glioblastomas are able 
to secrete immunosuppressive agents such as TGFß, IL-10 and Prostagalandin E2, and in addition, other cytokines, that may have immunosuppressive potential, like VEGF are secreted [47]. Further, as it has been shown, the antigen presenting cells of the brain, the so-called microglia cells, may act in an immunosuppressive way $[48,49]$. These and other mechanisms, as other components of tumor editing, typically lead to the establishment of immunosuppressive cellular elements of the tumor, like myeloid suppressor cells and regulatory $T$ cells $[\mathbf{2 9}, \mathbf{4 7}]$. For its malignant behaviour, a glioblastoma probably requires the maintenance of this immune privilege.

Thus, addressing this may be an effective therapeutic measure. By treatment with anti-CD25 antibodies alone, for example, protection of mice from an experiomental glioblastoma could be shown [50]; other approaches may include unspecific immunostimulation by cytokines like IFNgamma, IFN-beta or blockade of TGF-beta and other factors $[51,52]$. In mouse models, it was shown that stimulation of Toll-like receptors may convert the immunosuppressive role of the microglia towards a more immunostimulatory behavour [49].

By targeted approaches, like vaccination against particular tumor antigens, immunotherapy has been performed - still with not so impressive results. A reason probably is that the tumors can change their antigenetic profile in quite a rapid way.

Thus, an even much more individualized, targeted approach was developed which is immunotherapy by vaccination with dendritic cells after ex vivo stimulation and pulsing with autologous tumor antigens [53,54]. This is, indeed, by itself a completely individualized therapy: for each patient, a completely different vaccine is produced [53]. Being robust and simple, on the one hand, it has proven to be quite successful on the other, and might thus give an indication in which way to develop future strategies in the difficult field of glioblastoma therapy.

\section{Other approaches}

An approach opening very diverse new opportunities to the therapy of glioblastomas are nanoparticles facilitating the delivery of anti-tumor agents $[8,56]$. In recent in vitro or in vivo studies, they were used for the delivery of cytostatic drugs [57-60], cytotoxic peptides [61], antibodies [62,63], siRNA [64] or even oncolytic viruses [65], to deliver irradiation [66] or to improve imaging techniques [67]. The frame of this paper does not allow to discuss these new therapeutic opportunities in detail. Among the other approaches applied in the therapy of glioblastomas - besides new neurosurgical and irradiation methods, this implies in particular gene therapy, oncolytic viral therapy, or hyperthermia technology, again unfortunately none has proven efficacy in large numbers of patients, in spite of encouraging results in individual ones [1,7-9,54].

\section{Pediatric high-grade gliomas}

In children and adolescents, high grade gliomas do not only have a different biological behavior compared to those in adults $[4,5,15,24]$, they also show other patterns of molecular alterations [68-72]. Pediatric tumors in average go along with longer survival - although cure is also a very rare event in them - and they are more often found in the posterior fossa, leading to a higher degree of complete resection [5]. Further, the diffuse intrinsic pontine glioma (DIPG), a disease entity primarily defined by location in the pons and infiltrative growth behavior, is a disorder that is not at all observed in adults $[5,24,70]$.

Concerning the patterns of molecular alterations in pediatric high-grade gliomas, the subclassifications of adult high-grade gliomas are invalid in children. Pediatric glioblastoma only very rarely show EGFR alterations $[68,69]$. Although usually primary tumors, the pediatric glioblastomas often show p53 and PDGFRa alterations which, typically, are seen in secondary adult tumors, but IDH-1 mutations, however, are rare $[69,72]$.

On the other hand, several different genes affecting the histone remodelling system are overexpressed, particularly the histone $\mathrm{H} 3.3$ and the in alpha-thalassaemia/ mental retardation syndrome $X$-linked and death-domain associated protein (ATRX and DAXX) - genes; thus you may even conclude that mutations in $\mathrm{H} 3.3$ genes, ATRX and DAXX distinguish pediatric from adult GBM [69].

Also, a high number of cases overexpress Y-box-protein-1, a gene that may promote oncogenesis in children [71].

The biologically separate entity of DIPG (defined by location) has to a high degree receptor tyrosine kinaseras-phosphoinositide 3-kinase signaling pathway mostly involving PDGFRA and MET. Also amplifications of genes controlling retinoblastoma protein (RB) phosphorylation are often seen [70].

In summary, to detect possible mechanisms defining drug sensitivity in glioblastiomas, pediatric tumors should in any case be regarded as a separate entity, and separate algorithms for response detection or prediction have to be defined $[4,8,9,15]$.

\section{Discussion and conclusion}

As a result, we can conclude that numerous therapeutic approaches are at hand for the treatment of glioblastomas, however, none of them has thus far, as single agent, led to a breakthrough. In contrast, most of the studies have shown extremely disappointing results, in spite of the enthusiasm most of them had initially been started with.

Still, it may be possible that this is not due to a lack of efficacy but just to the lack of knowledge which patient should receive which treatment. Based on the assumption that each of the given agents might have some effect in a subgroup of patients but none in all, and none would be sufficient as monotherapy, the main task is to develop 
a scheme assigning each patient the best treatment combination for his individual tumor $[8,9]$.

To the requirement of sufficient evidence for personalized treatment strategies, however, there is no simple answer. Therapies based on individual tumor signatures necessarily imply low patient numbers which hampers statistical evidence. The more accurately an individual tumor is analysed the smaller the number of identical cases will be.

Probably, in furture protocols should be established randomizing patients between standard and individualized therapy, although even this could not easily prove or falsify the superiority of each individualized approach, since these individual therapies will necessarily be heterogeneous, possibly including effective and ineffective ones. A very important question in this context is whether the known genetic or epigenetic alterations of these brain tumors typically occur randomly or whether they occur in specific combinations, i.e., whether, for example, a secondary glioblastoma bearing the typical IDH-1 mutation will also show a specific pattern of EGFR, PI3 kinase or Erk activation, MGMT methylation, Histone acetylation, or NFkB activation. Or whether these different factors are just randomly distributed. Further, if there is a difference between the tumor bulk and the tumor stem cells, of course, it is the properties of the stem cells - and, perhaps, the migratory cells - that are the relevant ones.

First results indicate that, although there might may be some typical constellations, in fact the distribution of these factors is indeed extremely variable.

Each of the numerous substances that act in a molecular way depends on specific tumor related conditions, eg., EGFR or VEGF upregulation or MGMT methylation etc., and it is most likely that each substance does only help in a small subgroup of tumors. And each substance will only contribute by exerting a limited antitumoral effect. Thus, the problem will not be solved by just excluding those patients from a treatment in which this is ineffective. If we treat patients bearing a MGMT methylated tumor with TMZ alone, EGFR positive patients with EGFR antibodies alone, Integrin positive patients with Cilengitide alone, still most of them will not be cured. We will have to ask whether a combination of three, four or even more treatment modalities might be the right one for an individual patient $[32,35,37,45]$. And if so, each of the combinations will not only have to be assessed for effectivity and toxicity, but also for possible interactions [45]. One substance might induce upregulation or downregulation of factors that are relevant for other drugs. Using an antiangiogenetic drug that leads to tumor hypoxia, we will have to ask whether this induces alterations of the molecular setup in other parts of the cell. If a drug selectively targets a subgroup of tumor cells, we will not only have to ask whether these are the stem cells propagating the tumor, but also whether the intratumoral and systemic immunomodulation, the blood-brain barrier or the cytokine milieu in general will be altered leading to a change in the behaviour of the tumor as such.

If we will find a way to treat patients individually according to the very singular molecular makeup of his or her particular tumor - we will also have to keep in mind that this makeup may perhaps change - as has been observed already both in immunotherapy approaches, and by studying cell lines in vitro. Possibly, our concept will have to anticipate alterations the tumors might undergo under the treatment pressure, and to be able to do so, we will have to observe the individual treatment responses as carefully as possible.

It will only be possible to answer these question, if large numbers of tumors will be analysed - not only with regard to molecular setup and in vitro drug sensitivity, but also regarding the in vivo response to the given therapies. Larger studies aiming not only at testing drug efficacy in large patient cohorts, but also in collection of tumor materials are required $[8,9]$.

Finally, the development of new networks in the practical approach will be important. For a more individualized therapy, probably not only the histological diagnosis but numerous laboratory investigations including in vitro and animal studies and in silico investigations will be part of the standard workup performed in a new glioblastoma patient $[8,23,35]$.

To date, of course, it is completely open whether this approach will indeed lead to success. Individualized therapy will also require a new type of evidence based medicine, since the more detailed the analysis of individual patients becomes, the smaller the number of equal patients is - and finally, each patient would need a different treatment. To solve this problem, a new approach even in clinical statistics will be required.

\section{Competing interests}

The author declares no competing interests.

\section{Publication history}

Editor: Michael Hong-Sheng, Genomics Research Center, Taiwan. EIC: G.J. Peters, VU University Medical Center, Netherlands.

Received: 21-Jan-2013 Revised: 05-Apr-2013

Re-Revised: 06-Jun-2013 Accepted: 10-Jun-2013

Published: 27-Jun-2013

\section{References}

1. Weller M, Stupp R, Hegi M and Wick W: Individualized targeted therapy for glioblastoma: fact or fiction? Cancer J 2012, 18:40-4. | Article I PubMed

2. Rock K, McArdle O, Forde P, Dunne M, Fitzpatrick D, O'Neill B and Faul C: A clinical review of treatment outcomes in glioblastoma multiforme--the validation in a non-trial population of the results of a randomised Phase III clinical trial: has a more radical approach improved survival? Br J Radiol 2012, 85:e729-33. | Article I PubMed

3. Easaw JC, Mason WP, Perry J, Laperriere N, Eisenstat DD, Del Maestro R, Belanger K, Fulton D and Macdonald D: Canadian recommendations for the treatment of recurrent or progressive glioblastoma multiforme. Curr Oncol 2011, 18:e126-36. | Article | PubMed Abstract | PubMed Full Text 
4. MacDonald TJ, Aguilera D and Kramm CM: Treatment of high-grade glioma in children and adolescents. Neuro Oncol 2011, 13:1049-58. | Article | PubMed Abstract | PubMed Full Text

5. Wolff JE, Classen CF, Wagner S, Kortmann RD, Palla SL, Pietsch T, Kuhl J, Gnekow A and Kramm CM: Subpopulations of malignant gliomas in pediatric patients: analysis of the HIT-GBM database. J Neurooncol 2008, 87:155-64. | Article | PubMed

6. Stupp R, Hegi ME, Gilbert MR and Chakravarti A: Chemoradiotherapy in malignant glioma: standard of care and future directions. J Clin Oncol 2007, 25:4127-36. | Article | PubMed

7. Wick W, Weller M, Weiler M, Batchelor T, Yung AW and Platten $M$ : Pathway inhibition: emerging molecular targets for treating glioblastoma. Neuro Oncol 2011, 13:566-79. | Article | PubMed Abstract | PubMed Full Text

8. Rekers NH, Sminia P and Peters GJ: Towards tailored therapy of glioblastoma multiforme. J Chemother 2011, 23:187-99. | Article | PubMed

9. Wolff JE, Brown RE, Buryanek J, Pfister S, Vats TS and Rytting ME: Preliminary experience with personalized and targeted therapy for pediatric brain tumors. Pediatr Blood Cancer 2012, 59:27-33. | Article | PubMed

10. Martinez R, Martin-Subero Jl, Rohde V, Kirsch M, Alaminos M, Fernandez AF, Ropero S, Schackert $G$ and Esteller M: A microarraybased DNA methylation study of glioblastoma multiforme. Epigenetics 2009, 4:255-64. | Article | PubMed

11. Thompson EM, Frenkel EP and Neuwelt EA: The paradoxical effect of bevacizumab in the therapy of malignant gliomas. Neurology 2011, 76:87-93. | Article | PubMed Abstract | PubMed Full Text

12. Najafi M, Soltanian-Zadeh $H$, Jafari-Khouzani $K$, Scarpace $L$ and Mikkelsen T: Prediction of glioblastoma multiform response to bevacizumab treatment using multi-parametric MRI. PLoS One 2012, 7:e29945. | Article | PubMed Abstract | PubMed Full Text

13. Pope WB, Lai A, Nghiemphu P, Mischel P and Cloughesy TF: MRI in patients with high-grade gliomas treated with bevacizumab and chemotherapy. Neurology 2006, 66:1258-60. | Article | PubMed

14. Ananthnarayan S, Bahng J, Roring J, Nghiemphu P, Lai A, Cloughesy T and Pope WB: Time course of imaging changes of GBM during extended bevacizumab treatment. J Neurooncol 2008, 88:339-47. Article | PubMed

15. Classen CF, Warmuth-Metz M, Papke K, Trotter A, Wolff JE and Wagner S: Late response to radiochemotherapy in pediatric glioblastoma: report on two patients treated according to HIT-GBM protocols. Pediatr Hematol Oncol 2006, 23:631-7. | Article | PubMed

16. Bleeker FE, Molenaar RJ and Leenstra S: Recent advances in the molecular understanding of glioblastoma. J Neurooncol 2012, 108:11-27. | Article | PubMed Abstract | PubMed Full Text

17. MacDonald TJ, Stewart CF, Kocak M, Goldman S, Ellenbogen RG, Phillips P, Lafond D, Poussaint TY, Kieran MW, Boyett JM and Kun LE: Phase I clinical trial of cilengitide in children with refractory brain tumors: Pediatric Brain Tumor Consortium Study PBTC-012. J Clin Oncol 2008, 26:919-24. | Article | PubMed

18. Verhaak RG, Hoadley KA, Purdom E, Wang V, Qi Y, Wilkerson MD, Miller CR, Ding L, Golub T, Mesirov JP, Alexe G, Lawrence M, O'Kelly M, Tamayo P, Weir BA, Gabriel S, Winckler W, Gupta S, Jakkula L, Feiler HS, Hodgson JG, James CD, Sarkaria JN, Brennan C, Kahn A, Spellman PT, Wilson RK, Speed TP, Gray JW, Meyerson M, Getz G, Perou CM and Hayes DN: Integrated genomic analysis identifies clinically relevant subtypes of glioblastoma characterized by abnormalities in PDGFRA, IDH1, EGFR, and NF1. Cancer Cell 2010, 17:98-110. | Article | PubMed Abstract | PubMed Full Text

19. Pillay V, Allaf L, Wilding AL, Donoghue JF, Court NW, Greenall SA, Scott AM and Johns TG: The plasticity of oncogene addiction: implications for targeted therapies directed to receptor tyrosine kinases. Neoplasia 2009, 11:448-58. | Article | PubMed Abstract | PubMed Full Text

20. Hu J and Kesari S: The molecular basis for novel therapies. Cancer J 2012, 18:32-9. | Article | PubMed Abstract | PubMed Full Text

21. Geoerger B, Kieran MW, Grupp S, Perek D, Clancy J, Krygowski M,
Ananthakrishnan R, Boni JP, Berkenblit A and Spunt SL: Phase II trial of temsirolimus in children with high-grade glioma, neuroblastoma and rhabdomyosarcoma. Eur J Cancer 2012, 48:253-62. | Article | PubMed Abstract | PubMed Full Text

22. Butowski N, Chang SM, Lamborn KR, Polley MY, Pieper R, Costello JF, Vandenberg S, Parvataneni R, Nicole A, Sneed PK, Clarke J, Hsieh E, Costa BM, Reis RM, Hristova-Kazmierski M, Nicol SJ, Thornton DE and Prados MD: Phase II and pharmacogenomics study of enzastaurin plus temozolomide during and following radiation therapy in patients with newly diagnosed glioblastoma multiforme and gliosarcoma. Neuro Oncol 2011, 13:1331-8. | Article | PubMed Abstract I PubMed Full Text

23. Balik V, Mirossay P, Bohus P, Sulla I, Mirossay L and Sarissky M: Flow cytometry analysis of neural differentiation markers expression in human glioblastomas may predict their response to chemotherapy. Cell Mol Neurobiol 2009, 29:845-58. | Article | PubMed

24. Geoerger B, Hargrave D, Thomas F, Ndiaye A, Frappaz D, Andreiuolo F, Varlet P, Aerts I, Riccardi R, Jaspan T, Chatelut E, Le Deley MC, Paoletti X, Saint-Rose C, Leblond P, Morland B, Gentet JC, Meresse V and Vassal G: Innovative Therapies for Children with Cancer pediatric phase I study of erlotinib in brainstem glioma and relapsing/ refractory brain tumors. Neuro Oncol 2011, 13:109-18. | Article | PubMed Abstract | PubMed Full Text

25. Hoelzinger DB, Mariani L, Weis J, Woyke T, Berens TJ, McDonough WS, Sloan A, Coons SW and Berens ME: Gene expression profile of glioblastoma multiforme invasive phenotype points to new therapeutic targets. Neoplasia 2005, 7:7-16. | Article | PubMed Abstract | PubMed Full Text

26. Perry JR, Belanger K, Mason WP, Fulton D, Kavan P, Easaw J, Shields C, Kirby S, Macdonald DR, Eisenstat DD, Thiessen B, Forsyth P and Pouliot JF: Phase II trial of continuous dose-intense temozolomide in recurrent malignant glioma: RESCUE study. J Clin Oncol 2010 28:2051-7. | Article | PubMed

27. Sterba J, Valik D, Mudry P, Kepak T, Pavelka Z, Bajciova V, Zitterbart $\mathrm{K}$, Kadlecova $\mathrm{V}$ and Mazanek P: Combined biodifferentiating and antiangiogenic oral metronomic therapy is feasible and effective in relapsed solid tumors in children: single-center pilot study. Onkologie 2006, 29:308-13. | Article I PubMed

28. Tolcher AW, Gerson SL, Denis L, Geyer C, Hammond LA, Patnaik A, Goetz AD, Schwartz G, Edwards T, Reyderman L, Statkevich P, Cutler DL and Rowinsky EK: Marked inactivation of 06-alkylguanine-DNA alkyltransferase activity with protracted temozolomide schedules. Br J Cancer 2003, 88:1004-11. | Article | PubMed Abstract | PubMed Full Text

29. Haar CP, Hebbar P, Wallace GCt, Das A, Vandergrift WA, 3rd, Smith JA, Giglio P, Patel SJ, Ray SK and Banik NL: Drug resistance in glioblastoma: a mini review. Neurochem Res 2012, 37:1192-200. | Article | PubMed

30. Premkumar DR, Jane EP, Agostino NR, DiDomenico JD and Pollack IF: Bortezomib-induced sensitization of malignant human glioma cells to vorinostat-induced apoptosis depends on reactive oxygen species production, mitochondrial dysfunction, Noxa upregulation, Mcl-1 cleavage, and DNA damage. Mol Carcinog 2013, 52:118-33. | Article | PubMed

31. Friday BB, Anderson SK, Buckner J, Yu C, Giannini C, Geoffroy F, Schwerkoske J, Mazurczak M, Gross H, Pajon E, Jaeckle K and Galanis $\mathrm{E}$ : Phase II trial of vorinostat in combination with bortezomib in recurrent glioblastoma: a north central cancer treatment group study. Neuro Oncol 2012, 14:215-21. | Article | PubMed Abstract | PubMed Full Text

32. Gilbert MR, Gonzalez J, Hunter K, Hess K, Giglio P, Chang E, Puduvalli V, Groves MD, Colman H, Conrad C, Levin V, Woo S, Mahajan A, de Groot J and Yung WK: A phase I factorial design study of dosedense temozolomide alone and in combination with thalidomide, isotretinoin, and/or celecoxib as postchemoradiation adjuvant therapy for newly diagnosed glioblastoma. Neuro Oncol 2010, 12:1167-72. | Article | PubMed Abstract | PubMed Full Text

33. See SJ, Levin VA, Yung WK, Hess KR and Groves MD: 13-cis-retinoic acid in the treatment of recurrent glioblastoma multiforme. Neuro 
Oncol 2004, 6:253-8. | Article | PubMed Abstract | PubMed Full Text

34. Sareddy GR, Geeviman K, Ramulu C and Babu PP: The nonsteroidal anti-inflammatory drug celecoxib suppresses the growth and induces apoptosis of human glioblastoma cells via the NF-kappaB pathway. J Neurooncol 2012, 106:99-109. | Article | PubMed

35. Kang KB, Zhu C, Yong SK, Gao Q and Wong MC: Enhanced sensitivity of celecoxib in human glioblastoma cells: Induction of DNA damage leading to p53-dependent $\mathrm{G} 1$ cell cycle arrest and autophagy. Mol Cancer 2009, 8:66. | Article | PubMed Abstract | PubMed Full Text

36. Stockhammer F, Misch M, Koch A, Czabanka M, Plotkin M, Blechschmidt C, Tuettenberg J and Vajkoczy P: Continuous low-dose temozolomide and celecoxib in recurrent glioblastoma. J Neurooncol 2010, 100:407-15. | Article | PubMed

37. Kardosh A, Golden EB, Pyrko P, Uddin J, Hofman FM, Chen TC, Louie SG, Petasis NA and Schonthal AH: Aggravated endoplasmic reticulum stress as a basis for enhanced glioblastoma cell killing by bortezomib in combination with celecoxib or its non-coxib analogue, 2,5-dimethyl-celecoxib. Cancer Res 2008, 68:843-51. | Article | PubMed

38. Kubicek GJ, Werner-Wasik M, Machtay M, Mallon G, Myers T, Ramirez $M$, Andrews D, Curran WJ, Jr. and Dicker AP: Phase I trial using proteasome inhibitor bortezomib and concurrent temozolomide and radiotherapy for central nervous system malignancies. Int J Radiat Oncol Biol Phys 2009, 74:433-9. | Article | PubMed Abstract | PubMed Full Text

39. Phuphanich S, Supko JG, Carson KA, Grossman SA, Burt Nabors L, Mikkelsen T, Lesser G, Rosenfeld S, Desideri S and Olson JJ: Phase 1 clinical trial of bortezomib in adults with recurrent malignant glioma. J Neurooncol 2010, 100:95-103. | Article | PubMed

40. Takano S: Glioblastoma angiogenesis: VEGF resistance solutions and new strategies based on molecular mechanisms of tumor vessel formation. Brain Tumor Pathol 2012, 29:73-86 . | Article | PubMed

41. Knights MJ, Kyle $S$ and Ismail A: Characteristic features of stem cells in glioblastomas: from cellular biology to genetics. Brain Pathol 2012, 22:592-606. | Article | PubMed

42. Friedmann-Morvinski D, Bushong EA, Ke E, Soda Y, Marumoto T, Singer O, Ellisman MH and Verma IM: Dedifferentiation of neurons and astrocytes by oncogenes can induce gliomas in mice. Science 2012, 338:1080-4. | Article | PubMed Abstract | PubMed Full Text

43. Riemenschneider MJ, Hegi ME and Reifenberger G: MGMT promoter methylation in malignant gliomas. Target Oncol 2010, 5:161-5. | Article I PubMed

44. Gilbert MR, Kuhn J, Lamborn KR, Lieberman F, Wen PY, Mehta M, Cloughesy T, Lassman AB, Deangelis LM, Chang $S$ and Prados M: Cilengitide in patients with recurrent glioblastoma: the results of NABTC 03-02, a phase II trial with measures of treatment delivery. $J$ Neurooncol 2012, 106:147-53. | Article | PubMed

45. Lomonaco SL, Finniss S, Xiang C, Lee HK, Jiang W, Lemke N, Rempel SA, Mikkelsen T and Brodie C: Cilengitide induces autophagymediated cell death in glioma cells. Neuro Oncol 2011, 13:857-65. | Article | PubMed Abstract | PubMed Full Text

46. Kesari S, Schiff D, Henson JW, Muzikansky A, Gigas DC, Doherty L, Batchelor TT, Longtine JA, Ligon KL, Weaver S, Laforme A, Ramakrishna N, Black PM, Drappatz J, Ciampa A, Folkman J, Kieran $\mathrm{M}$ and Wen PY: Phase II study of temozolomide, thalidomide, and celecoxib for newly diagnosed glioblastoma in adults. Neuro Oncol 2008, 10:300-8. | Article | PubMed Abstract | PubMed Full Text

47. Puduvalli VK, Giglio P, Groves MD, Hess KR, Gilbert MR, Mahankali $\mathrm{S}$, Jackson EF, Levin VA, Conrad CA, Hsu SH, Colman H, de Groot JF, Ritterhouse MG, Ictech SE and Yung WK: Phase II trial of irinotecan and thalidomide in adults with recurrent glioblastoma multiforme. Neuro Oncol 2008, 10:216-22. | Article | PubMed Abstract | PubMed Full Text

48. Thomas AA, Ernstoff MS and Fadul CE: Immunotherapy for the treatment of glioblastoma. Cancer J 2012, 18:59-68. | Article | PubMed Abstract I PubMed Full Text

49. Tran Thang NN, Derouazi M, Philippin G, Arcidiaco S, Di BerardinoBesson W, Masson F, Hoepner S, Riccadonna C, Burkhardt K, Guha
A, Dietrich PY and Walker PR: Immune infiltration of spontaneous mouse astrocytomas is dominated by immunosuppressive cells from early stages of tumor development. Cancer Res 2010, 70:4829-39. I Article I PubMed

50. Kees T, Lohr J, Noack J, Mora R, Gdynia G, Todt G, Ernst A, Radlwimmer B, Falk CS, Herold-Mende C and Regnier-Vigouroux A: Microglia isolated from patients with glioma gain antitumor activities on poly (I:C) stimulation. Neuro Oncol 2012, 14:64-78. | Article I PubMed Abstract I PubMed Full Text

51. Maes W and Van Gool SW: Experimental immunotherapy for malignant glioma: lessons from two decades of research in the GL261 model. Cancer Immunol Immunother 2011, 60:153-60. | Article I PubMed

52. Jackson C, Ruzevick J, Phallen J, Belcaid Z and Lim M: Challenges in immunotherapy presented by the glioblastoma multiforme microenvironment. Clin Dev Immunol 2011, 2011:732413. | Article | PubMed Abstract | PubMed Full Text

53. Smith KE, Fritzell S, Badn W, Eberstal S, Janelidze S, Visse E, Darabi $A$ and Siesjo P: Cure of established GL261 mouse gliomas after combined immunotherapy with GM-CSF and IFNgamma is mediated by both CD8+ and CD4+ T-cells. Int J Cancer 2009, 124:630-7. | Article I PubMed

54. Van Gool S, Maes W, Ardon H, Verschuere T, Van Cauter S and De Vleeschouwer S: Dendritic cell therapy of high-grade gliomas. Brain Pathol 2009, 19:694-712. | Article | PubMed

55. Wollmann G, Ozduman K and van den Pol AN: Oncolytic virus therapy for glioblastoma multiforme: concepts and candidates. Cancer J 2012, 18:69-81 | Article | PubMed Abstract | PubMed Full Text

56. Nduom EK, Bouras A, Kaluzova M and Hadjipanayis CG: Nanotechnology applications for glioblastoma. Neurosurg Clin N Am 2012, 23:439-49. | Article | PubMed

57. Gu G, Xia H, Hu Q, Liu Z, Jiang M, Kang T, Miao D, Tu Y, Pang Z, Song Q, Yao L, Chen H, Gao X and Chen J: PEG-Co-PCL nanoparticles modified with MMP-2/9 activatable low molecular weight protamine for enhanced targeted glioblastoma therapy. Biomaterials 2013, 34:196208. | Article | PubMed

58. Xin H, Sha X, Jiang X, Zhang W, Chen L and Fang X: Anti-glioblastoma efficacy and safety of paclitaxel-loading Angiopep-conjugated dual targeting PEG-PCL nanoparticles. Biomaterials 2012, 33:8167-76. | Article | PubMed

59. Orza A, Soritau O, Tomuleasa C, Olenic L, Florea A, Pana O, Bratu I, Pall E, Florian S, Casciano D and Biris AS: Reversing chemoresistance of malignant glioma stem cells using gold nanoparticles. Int J Nanomedicine 2013, 8:689-702. | Article | PubMed Abstract | PubMed Full Text

60. Staffhorst RW, van der Born K, Erkelens CA, Hamelers IH, Peters GJ, Boven $\mathrm{E}$ and de Kroon Al: Antitumor activity and biodistribution of cisplatin nanocapsules in nude mice bearing human ovarian carcinoma xenografts. Anticancer Drugs 2008, 19:721-7. | Article | PubMed

61. Agemy L, Friedmann-Morvinski D, Kotamraju VR, Roth L, Sugahara KN, Girard OM, Mattrey RF, Verma IM and Ruoslahti E: Targeted nanoparticle enhanced proapoptotic peptide as potential therapy for glioblastoma. Proc Natl Acad Sci U S A. 2011, 108:17450-5. | Article | PubMed Abstract | PubMed Full Text

62. Hadjipanayis CG, Machaidze R, Kaluzova M, Wang L, Schuette AJ, Chen $\mathrm{H}, \mathrm{Wu} \mathrm{X}$ and Mao H: EGFRvIII antibody-conjugated iron oxide nanoparticles for magnetic resonance imaging-guided convectionenhanced delivery and targeted therapy of glioblastoma. Cancer Res 2010, 70:6303-12. | Article | PubMed Abstract | PubMed Full Text

63. Wankhede M, Bouras A, Kaluzova M and Hadjipanayis CG: Magnetic nanoparticles: an emerging technology for malignant brain tumor imaging and therapy. Expert Rev Clin Pharmacol 2012, 5:173-86. | Article | PubMed Abstract | PubMed Full Text

64. Perez AP, Cosaka ML, Romero EL and Morilla MJ: Uptake and intracellular traffic of siRNA dendriplexes in glioblastoma cells and macrophages. Int J Nanomedicine 2011, 6:2715-28. | Article | PubMed Abstract | PubMed Full Text 
65. Dudu V, Rotari V and Vazquez M: Sendai virus-based liposomes enable targeted cytosolic delivery of nanoparticles in brain tumorderived cells. J Nanobiotechnology 2012, 10:9. | Article | PubMed Abstract | PubMed Full Text

66. Phillips WT, Goins B, Bao A, Vargas D, Guttierez JE, Trevino A, Miller JR, Henry J, Zuniga R, Vecil G and Brenner AJ: Rhenium-186 liposomes as convection-enhanced nanoparticle brachytherapy for treatment of glioblastoma. Neuro Oncol 2012, 14:416-25. | Article | PubMed Abstract | PubMed Full Text

67. Iqbal U, Albaghdadi H, Luo Y, Arbabi M, Desvaux C, Veres T, Stanimirovic D and Abulrob A: Molecular imaging of glioblastoma multiforme using anti-insulin-like growth factor-binding protein-7 single-domain antibodies. Br J Cancer 2010, 103:1606-16. | Article | PubMed Abstract | PubMed Full Text

68. Qu HQ, Jacob K, Fatet S, Ge B, Barnett D, Delattre O, Faury D, Montpetit A, Solomon L, Hauser P, Garami M, Bognar L, Hansely Z, Mio R, Farmer JP, Albrecht S, Polychronakos C, Hawkins C and Jabado $\mathrm{N}$ : Genome-wide profiling using single-nucleotide polymorphism arrays identifies novel chromosomal imbalances in pediatric glioblastomas. Neuro Oncol 2010, 12:153-63. | Article | PubMed Abstract | PubMed Full Text

69. Schwartzentruber J, Korshunov A, Liu XY, Jones DT, Pfaff E, Jacob K, Sturm D, Fontebasso AM, Quang DA and Tonjes M et al.: Driver mutations in histone $\mathrm{H} 3.3$ and chromatin remodelling genes in paediatric glioblastoma. Nature 2012, 482:226-31. | Article | PubMed

70. Paugh BS, Broniscer A, Qu C, Miller CP, Zhang J, Tatevossian RG, Olson JM, Geyer JR, Chi SN, da Silva NS, Onar-Thomas A, Baker JN, Gajjar A, Ellison DW and Baker SJ: Genome-wide analyses identify recurrent amplifications of receptor tyrosine kinases and cell-cycle regulatory genes in diffuse intrinsic pontine glioma. J Clin Oncol 2011, 29:39994006. | Article | PubMed Abstract | PubMed Full Text

71. Faury D, Nantel A, Dunn SE, Guiot MC, Haque T, Hauser P, Garami M, Bognar L, Hanzely Z, Liberski PP, Lopez-Aguilar E, Valera ET, Tone LG, Carret AS, Del Maestro RF, Gleave M, Montes JL, Pietsch T, Albrecht $\mathrm{S}$ and Jabado N: Molecular profiling identifies prognostic subgroups of pediatric glioblastoma and shows increased YB-1 expression in tumors. J Clin Oncol 2007, 25:1196-208. | Article | PubMed

72. Bax DA, Little SE, Gaspar N, Perryman L, Marshall L, Viana-Pereira M, Jones TA, Williams RD, Grigoriadis A, Vassal G, Workman P, Sheer $D$, Reis RM, Pearson AD, Hargrave D and Jones C: Molecular and phenotypic characterisation of paediatric glioma cell lines as models for preclinical drug development. PLoS One 2009, 4:e5209. | Article | PubMed Abstract | PubMed Full Text

\section{Citation:}

Classen CF: Glioblastomas: are individual therapies required for individual tumors? J Cancer Ther Res 2013, 2:17. http://dx.doi.org/10.7243/2049-7962-2-17 